\title{
Tinjauan Yuridis Penggolongan Penduduk Dalam Pembuatan Keterangan Waris
}

\author{
Sari Elsye Priyanti \\ Pascasarjana Universitas Islam Indonesia \\ Jln. Cik Di Tiro No. 1 Yogyakarta \\ sari.elsye@gmail.com
}

\begin{abstract}
This study examines the classification of indigenous and non-indigenous populations in formulating the information regarding the heir from the perspective of eliminating racial and ethnic discrimination. There are two main issues raised in this study, firstly, whether the population classification in Perkaban No. 3 of 1997 in accordance with Law No. 40 of 2008 on the Elimination of Racial and Ethnic Discrimination. Secondly, whether the difference between the authorities in providing the certificate of inheritance according to Perkaban No. 3 of 1997 can provide legal certainty. This research is a normative juridical study with a statutory approach. This study concluded that, first Article 111 of Perkaban No. 3 of 1997 concerning the classification of the population in the making of a certificate of inheritence contrary to Law No. 40 of 2008 on the Elimination of Racial and Ethnic Discrimination. Second, the difference between the authorities giving the certificate of inheritance according to Perkaban No. 3 of 1997 has guaranteed legal certainty, as Perkaban No. 3 of 1997 specifically regulates the certificate of inheritance. However, this regulation still needs improvement in the future.
\end{abstract}

Keywords: Cerificate of inheritence; classification of population; racial and ethnic discrimination

\begin{abstract}
Abstrak
Penelitian ini mengkaji mengenai pengolongan penduduk pribumi dan non pribumi pada pembuatan keterangan waris ditinjau dari perspektif penghapusan diskriminasi ras dan etnis. Terdapat dua permasalahan utama yang diangkat dalam penelitian ini ini, yaitu pertama apakah penggolangan penduduk dalam Perkaban No. 3 Tahun 1997 sesuai dengan UU No. 40 Tahun 2008 tentang Penghapusan Diskriminasi Ras dan Etnis. Kedua, apakah pembedaan pihak yang berwenang dalam memberikan surat keterangan waris menurut Perkaban No. 3 Tahun 1997 dapat memberikan kepastian hukum. Penelitian ini merupakan penelitian yuridis normatif dengan pendekatan perundang-undangan. Penelitian ini menyimpulkan bahwa, pertama Perkaban No. 3 Tahun 1997 Pasal 111 tentang penggolongan penduduk dalam pembuatan surat keterangan waris bertentangan dengan UU No. 40 Tahun 2008 tentang Penghapusan Diskriminasi Ras dan Etnis. Kedua, pembedaan pihak yang berwenang memberikan surat keterangan waris menurut Perkaban No. 3 Tahun 1997 sudah menjamin kepastian hukum, karena Perkaban No. 3 Tahun 1997 yang mengatur secara khusus mengenai surat keterangan waris. Namun, peraturan ini tetap perlu pembenahan ke depannya.
\end{abstract}

Kata-kata Kunci: Penggolongan penduduk; surat keterangan waris; diskriminasi ras dan etnis 


\section{Pendahuluan}

Seorang ahli waris tidak dapat serta merta menguasai dan melakukan balik nama terhadap harta warisan yang diberikan Pewaris. Dalam hal ini ahli waris harus melakukan perbuatan hukum terhadap harta warisan yang menjadi haknya dengan keterangan waris sebagai syarat utamanya. ${ }^{1}$ Secara spesifik sebenarnya belum ada dasar hukum yang mengatur mengenai pembuatan surat keterangan ahli waris, sehingga dasar peraturannya dipersamakan dengan ketentuan Peraturan Menteri Negara Agraria/Kepala Badan Pertanahan Nasional Nomor 3 Tahun 1997 tentang Ketentuan Pelaksanaan Peraturan Pemerintah Nomor 24 Tahun 1997 tentang Pendaftaran Tanah sebagaimana diubah dengan Peraturan Kepala Badan Pertanahan Nasional Republik Indonesia Nomor 8 Tahun 2012 (selanjut disebut dengan Perkaban Nomor 3 Tahun 1997), dalam ranah peralihan hak atas tanah yang memerlukan alas hak berupa keterangan waris yang dibuat oleh pejabat yang berwenang. Namun yang menjadi permasalahan adalah masih terdapat penggolongan penduduk yang termuat di dalamnya.

Penggolongan penduduk dalam proses peralihan hak atas tanah karena pewarisan diatur di dalam Permen Agraria/Kepala BPN tentang Pendaftaran atas tanah Pasal 111 ayat (1) huruf c angka 4. Surat tanda bukti sebagai ahli waris ditujukan pada beberapa golongan penduduk yaitu:

- bagi warga negara Indonesia penduduk asli: surat keterangan ahli waris yang dibuat oleh para ahli waris dengan disaksikan oleh 2 (dua) orang saksi dan dikuatkan oleh Kepala Desa/Kelurahan dan Camat tempat tinggal pewaris pada waktu meninggal dunia;

- bagi warga negara Indonesia Keturunan Tionghoa: akta keterangan hak mewaris dari Notaris,

- bagi warga negara Indonesia keturunan Timur Asing lainnya: surat keteragan waris dari Balai Harta Peninggalan.

Peraturan mengenai penggolongan penduduk yang mengacu pada Pasal 111 Perkaban No. 3 Tahun 1997 tersebut masih berlaku hingga saat ini yang 
menyebabkan adanya perbedaan penanganan pembuatan keterangan waris. ${ }^{2}$ Pada dasarnya ketentuan dalam Perkaban No. 3 Tahun 1997 mengenai penggolongan penduduk tersebut mengacu pada aturan yang sudah 'kuno' yaitu Pasal 163 I.S. yang merupakan aturan warisan jaman penjajahan pemerintah Hindia Belanda yang menerapkan prinsip penggolongan penduduk. ${ }^{3}$ Berdasarkan peraturan ini, Notaris dalam membuat dokumen surat keterangan waris sangat memperhatikan tiga penggolongan penduduk tersebut, karena terkait dengan berwenang atau tidaknya Notaris membuat surat keterangan waris tersebut. ${ }^{4}$ Bahkan dalam kasus percampuran etnis karena perkawinan menimbulkan ketidakjelasan penentuan golongan penduduk anak hasil kawin campur tersebut. ${ }^{5}$ Sehingga, penerapan Perkaban No. 3 Tahun 1997 Pasal 111 ini sangat problematis, baik dari segi administratif maupun secara substansi perlindungan hak asasi manusia.

Ketentuan Perkaban No. 3 Tahun 1997 Pasal 111 tersebut merupakan ketentuan kewarisan di bidang pertanahan yang mengacu pada Undang-Undang Nomor 5 Tahun 1960 tentang Peraturan Dasar Pokok-Pokok Agraria pada Pasal 19 megenai Pendaftaran Tanah. Kelahiran UUPA dimaknai sebagai revolusi hukum agraria baru yang nasional, dan dapat menghapus dualisme sistem hukum pertanahan di Indonesia, yang berlaku bagi semua golongan. Sehingga, semangat Perkaban No. 3 Tahun 1997 seharusnya mengacu pada semangat UUPA tersebut. UUPA pada dasarnya juga membawa amanat konstitusi 1945 dalam membangun masyarakat yang adil dan makmur, dimana hukum agraria nasional merupakan penjelmaan dari Negara dan cita-cita bangsa berdasarkan Pancasila. ${ }^{6}$ Pancasila sebagai falsafah kenegaraan (staatsidee) cita negara yang berfungsi sebagai dasar

2 I Gusti Kade Prabawa Maha Yoga, Afifah Kusumadara dan Endang Sri Kawuryan, "Kewenangan Notaris dalam Pembuatan Surat Keterangan Waris untuk Warga Negara Indonesia," Jurnal Ilmiab Pendidikan Pancasila dan Kewarganegaraan, Vol. 3 Nomor 2 Desember 2018, hlm. 137

${ }^{3}$ Ibid

${ }^{4}$ RM. Henky Wibawa Bambang Pramana, Suhariningsih, Abdul Rachmad Boediono, "Analisis Yuridis Surat Keterangan Ahli Waris Sebagai Alat Bukti”, Jurnal Hukum, Magister Ilmu Hukum dan Kenotariatan 2014, Universitas Brawijaya, hlm. 3

${ }^{5}$ Ibid., hlm. $3-4$

${ }_{6}^{6}$ Penjelasan Umum Undang-Undang Nomor 5 Tahun 1960 Tentang Peraturan Dasar Pokok-Pokok Agraris (disingkat UUPA) angka I Tujuan Undang-Undang Pokok Agraria: Hukum agraria yang baru harus memberi kemungkinan tercapainya fungsi bumi, air, dan ruang angkasa dan sesuai dengan kepentingan rakyat dan negara. Hukum agraria nasional harus mampu mewujudkan penjelmaan dari azas kerokhanian, negara dan cita-cita bangsa, yaitu Ketuhanan Yang Maha Esa, Perikemanusiaan, Kebangsaan, Kerakyatan dan Keadilan Sosial serta khususnya pelaksanaan daripada ketentuan Pasal 33 Undang-Undang Dasar dan Garis Besar Haluan Negara. 
filsafat bangsa (filosofische groundslag), dan dasar negara (common platform) di antara sesama warga masyarakat dalam konteks kehidupan bernegara, merupakan kesepakatan pertama penyangga konstitusionalisme, yang menunjukkan hakikat Pancasila sebagai ideologi yang terbuka. Memperhatikan sila-sila yang terkandung dalam Pancasila, dengan jelas dan tegas mengakui eksistensi nilai-nilai kemanusiaan baik individual maupun kolektivitas, sehingga Hak Asasi Manusia (HAM) dalam pandangan Pancasila sebagai ideologi negara yang mengakui eksistensi nilai-nilai kemanusiaan yang harus dihargai dan dihormati. ${ }^{7}$ Demikian tercermin pada :

- Sila ke I "Ketuhanan Yang Maha Esa"; pengakuan atas hak untuk beragama

- Sila ke II "Kemanusiaan Yang Adil dan Beradab" ; pengakuan eksistensi kemanusiaan, keadilan kemanusiaan dengan cara-cara yang manusiawi

- Sila ke III "Persatuan Indonesia" ; pengakuan atas kebersamaan dan persatuan

- Sila ke IV "Kerakyatan yang Dipimpin oleh Hikmah Kebijaksanaan dalam Permusyawaratan Perwakilan" ; pengakuan atas nilai-nilai demokrasi, berkumpul, mengeluarkan pendapat danpikiran

- Sila ke V "Keadilan Sosial Bagi Seluruh Rakyat Indonesia" ; pengakuan tentang nilai-nilai keadilan yang universal.

Indonesia sebagai bangsa dengan ideologi Pancasila, memandang HAM sebagai hak-hak kodratiah dan fundamental kemanusiaan, sehingga konsentrasi HAM sifatnya tertuju baik bagi individual maupun bagi manusia secara kolektif yang tercermin dalam sila-sila Pancasila. ${ }^{8}$ Pasca kemerdekaan dan diberlakukannya hukum nasional berdasarkan konstitusi, para pendiri bangsa mempertegas kekuatan persatuan dan menghilangkan unsur diskriminasi yang mengancam negara, melalui amandemen ke 2 UUD NRI Tahun 1945 dengan penambahan Bab XA mengenai HAM. Reformasi birokrasi menuju pemerintahan yang bersih dari unsur korupsi, kolusi dan nepotisme juga menjadi pendorong penghapusan praktik penggolongan penduduk berdasarkan kesamaan ras, etnis dan agama, dan disusunlah Undang-Undang No. 40 Tahun 2008 tentang Penghapusan Diskriminasi Ras dan Etnis (selanjutnya disebut UU No. 40 Tahun 2008) sebagai legitimasi dihapusnya diskriminasi ras dan etnis di Indonesia.

${ }^{7}$ Nurul Qamar, Hak Asasi Manusia Dalam Negara Hukum Demokrasi (Human Rights In Democratiche Rechtsstaat), Sinar Grafika, Jakarta Timur, 2013, hlm. 94

${ }^{8}$ Ibid., hlm. 95 
Dengan adanya UU No. 40 Tahun 2008 tersebut, apakah penggolongan penduduk dalam Perkaban No. 3 Tahun 1997 masih relevan untuk diberlakukan? Penelitian ini akan mengulas mengenai kontekstualisasi penggolongan penduduk dalam pembuatan surat keterangan waris yang mengacu pada hukum penghapusan diskriminasi ras dan etnis.

\section{Rumusan Masalah}

Pertama, apakah penggolongan penduduk pribumi dan non pribumi pada Pasal 111 ayat (1) huruf c angka 4 Peraturan Menteri Negara Agraria/Kepala BPN No. 3 Tahun 1997 tentang Ketentuan Pelaksanaan Peraturan Pemerintah No. 24 Tahun 1997 tentang Pendaftaran Tanah sesuai dengan Undang-Undang No. 40 Tahun 2008 tentang Penghapusan Diskriminasi Ras dan Etnis? Kedua, apakah pembedaan pihak yang berwenang membuat surat tanda bukti sebagai ahli waris dalam Pasal 111 ayat (1) huruf c angka 4PMNA/Kepala BPN No. 3 Tahun 1997 tentang Ketentuan Pelaksanaan Peraturan Pemerintah No. 24 Tahun 1997 tentang Pendaftaran Tanah dapat memberikan kepastian hukum bagi ahli waris?

\section{Tujuan Penelitian}

Pertama, untuk mengetahui, mengidentifikasi dan mengkaji lebih dalam penggolongan penduduk yang terdapat pada Pasal 111 ayat (1) huruf c angka 4 Peraturan Menteri Agraria/Kepala BPN No. 3 Tahun 1997 tentang Ketentuan Pelaksanaan Peraturan Pemerintah No. 24 Tahun 1997 tentang Pendaftaran Tanah terhadap Undang-Undang No. 40 Tahun 2008 tentang Penghapusan Diskriminasi Ras dan Etnis. Kedua, untuk mengetahui, mengidentifikasi dan mengkaji lebih dalam pembedaan pihak yang berwenang membuat surat tanda bukti sebagai ahli waris dalam Pasal 111 ayat (1) huruf c angka 4 PMNA/Kepala BPN No. 3 Tahun 1997 tentang Ketentuan Pelaksanaan Peraturan Pemerintah No. 24 Tahun 1997 tentang Pendaftaran Tanah dalam memberikan kepastian hukum bagi ahli waris.

\section{Metode Penelitian}

Penelitian ini merupakan penelitian hukum normatif dengan pendekatan perundang-undangan. Bahan hukum penelitian ini berupa bahan hukum primer 
yang terdiri dari peraturan perundang-undangan antara lain: Undang-Undang Nomor 40 Tahun 2008 tentang Penghapusan Diskriminasi Ras dan Etnis, UndangUndang Nomor 2 Tahun 2014 tentang Perubahan atas Undang-Undang Nomor 30 Tahun 2004 tentang Jabatan Notaris, Peraturan Menteri Negara Agraria/Kepala BPN No. 3 Tahun 1997 Tentang Ketentuan Pelaksanaan Peraturan Pemerintah No. 24 Tahun 1997 Tentang Pendaftaran Tanah, Undang-Undang Nomor 12 Tahun 2006 tentang Kewarganegaraan Republik Indonesia. Selain itu, penelitian ini juga menggunakan bahan hukum skunder berupa buku-buku, jurnal, artikel dan literatur lain yang berkenaan dengan permasalahan yang dibahas. Bahan hukum dikumpulkan melalui metode studi pustaka dan dianalisis secara deskriptif kualitatif.

\section{Hasil Penelitian dan Pembahasan}

Penggolongan Penduduk Pribumi dan Non Pribumi pada Pasal 111 ayat (1) huruf c angka 4 PMNA/Kepala BPN No. 3 Tahun 1997 tentang Pelaksanaan PP No. 24 Tahun 1997 tentang Pendaftaran Tanah Ditinjau dari Undang-Undang No. 40 Tahun 2008 tentang Penghapusan Diskriminasi Ras dan Etnis

Pasal 131 Indische Staatsregeling (IS) dan Pasal 163 IS merupakan salah satu penyebab terjadinya pluralisme hukum di bidang keperdataan. Pada ketentuan Pasal 163 IS, penduduk Hindia-Belanda dibagi atas 3 (tiga) golongan yaitu golongan Eropa, golongan Bumiputera dan golongan Timur Asing. ${ }^{9}$ Pembagian kelompok tersebut diikuti dengan pembagian kuasa hukum yang berlaku bagi masing-masing golongan tersebut berdasarkan Pasal 131 IS.

Penggolongan penduduk berdasarkan Pasal 163 Indische Staatsregeling (IS) adalah sebagai berikut: ${ }^{10}$

1. Golongan Eropa meliputi semua orang Belanda, semua orang yang berasal dari Eropa tetapi bukan dari Belanda, semua orang Jepang, semua orang yang berasal dari tempat lain, tetapi tidak termasuk orang Belanda, yang di negaranya tunduk kepada hukum keluarga dan asas-asasnya sama dengan hukum Belanda. Anak sah atau yang diakui menurut Undang-Undang dan keturunan selanjutnya dari orang-orang yang berasal dari Eropa bukan Belanda atau Eropa yang lahir di Hindia Belanda;

${ }^{9}$ F.X. Suhardana, Hukum Perdata, Buku Panduan Mahasiswa, PT. Prenhallindo, Jakarta, 2001, hlm. 14-15

${ }^{10}$ Habib Adjie, Pembuktian Sebagai Abli Waris Dengan Akta Notaris, Mandar Maju, Bandung, 2008, hlm. 5 
2. Golongan Bumiputera, meliputi semua orang yang termasuk rakyat asli Hindia-Belanda dan tidak pernah pindah ke dalam golongan penduduk lain dari golongan Bumiputera, golongan penduduk lainnya yang telah meleburkan diri menjadi golongan Bumiputera dengan cara meniru atau mengikuti kehidupan sehari-hari golongan Bumiputera dan meninggalkan hukumnya atau karena perkawinan;

3. Golongan Timur Asing, meliputi Penduduk yang tidak termasuk golongan Eropa dan golongan Bumiputera. Golongan ini dibedakan atas Timur Asing Tionghoa dan Timur Asing Bukan Tionghoa seperti Arab dan India.

Sedangkan Pasal 131 Indische Staatsregeling (IS) mengadakan 3 golongan hukum yang berlaku untuk tiap golongan penduduk sebagaimana di atas, dan ditegaskan sebagai berikut:11

1. Hukum perdata dan dagang, hukum pidana beserta hukum acara perdata dan hukum acara pidana harus dikodifisir, yaitu diletakkan dalam suatu kitab undang-undnag. Untuk golongan bangsa Eropa harus dianut (dicontoh) perundang-undangan yang berlau di negeri Belanda (asas konkordansi)

2. Untuk golongan bangsa Indonesia Asli dan Timur Asing, jika ternyata kebutuhan masyarakat mereka menghendakinya, dapatlah peraturanperaturan untuk bangsa Eropa dinyatakan berlaku bagi mereka, baik seutuhnya maupun dengan perubahan-perubahan, dan juga diperbolehkan membuat suatu peraturan baru bersama, untuk lainnya harus diindahkan aturan-aturan yang berlaku di kalangan mereka, dari aturan-aturan mana boleh diadakan penyimpangan jika dminta oleh kepentingan umum atau kebutuhan kemasyarakatan mereka.

3. Orang Indonesia Asli dan orang Timur Asing, sepanjang mereka belum ditundukkan di bawah suatu peraturan bersama dengan orang Eropa, diperbolehkan menundukkan diri pada hukum yang berlaku di Eropa, penundukan boleh dilkukan baik seluruhnya maupun hanya mengenai suatu perbuatan tertentu.

Setiap golongan penduduk tersebut berlaku hukum yang berbeda-beda, akan tetapi dalam perkembangannya Pasal 131 dan Pasal 163 IS telah dicabut pemberlakuanya melalui Instruksi Presidium Kabinet Ampera Nomor 31/U/IN/12/1966 tertanggal 27 Desember 1966 dan berlaku tanggal 1 Januari 1967, dengan tujuan demi tercapainya pembinaan kesatuan bangsa Indonesia yang bulat dan homogen. ${ }^{12}$ Namun penggolongan penduduk masih diterapkan dalam

\footnotetext{
${ }^{11}$ Ibid, hlm. 6-7

12 Herlin Budiono, Kumpulan Tulisan Hukum Perdata di Bidang Kenotariatan, Citra Aditya Bakti, Bandung, 2013, hlm. 84
} 
pembuatan surat tanda bukti sebagai ahli waris berdasarkan ketentuan Pasal 111 ayat (1) angka 4 Perkaban No. 3 Tahun 1997.

Akibat tidak adanya unifikasi hukum waris di Indonesia, hingga saat ini belum ada dasar hukum yang mengatur mengenai pembuatan surat keterangan ahli waris. Sehingga dasar peraturannya dipersamakan dengan ketentuan dalam Perkaban No. 3 Tahun 1997 tersebut, dalam ranah peralihan hak atas tanah yang memerlukan alas hak berupa keterangan waris yang dibuat oleh pejabat/pihakpihak yang berwenang.

Berbagai peraturan perundang-undangan di Indonesia telah menegaskan mengenai persamaan di hadapan hukum, diantaranya telah dipertegas dalam Undang-Undang Dasar Negara Republik Indonesia Tahun 1945 Pasal 26 ayat (1) dan Pasal 27 ayat (1) dan Pasal 28B ayat (2), Pasal 28D ayat (1) dan (4), Pasal 28I ayat (2) yang menyatakan: Pasal 26 ayat (1)
"Yang menjadi warga negara ialah orang-orang bangsa Indonesia asli
dan orang-orang bangsa lain yang disahkan dengan undang-undang
sebagai warga Negara."
Pasal 27 ayat (1)
"Segala warga negara bersamaan kedudukannya di dalam hukum dan
pemerintahan dan wajib menjunjung hukum dan pemerintahan itu
dengan tidak ada kecualinya."
Pasal 28B ayat (2)

"Setiap anak berhak atas kelangsungan hidup, tumbuh, dan berkembang serta berhak atas perlindungan dari kekerasan dan diskriminasi. Pasal 28D ayat (1) Setiap orang berhak atas pengakuan, jaminan, perlidungan, dan kepastian hukum yang adil serta perlakuan yang sama di hadapan hukum. Dan ayat (4) Setiap orang berhak atas status kewarganegaraan."

Pasal 28I ayat (2)

"Setiap orang berhak bebas dari perlakuan yang bersifat diskriminatif atas dasar apapun dan berhak mendapatkan perlindungan terhadap perlakuan yang bersifat diskriminatif itu."

Lebih lanjut diatur khusus mengenai warga negara dalam Undang-Undang Nomor 12 Tahun 2006 tentang Kewarganegaraan (selanjutnya disebut UU Kewarganegaraan). Ketentuan mengenai Kewarganegaraan di Indonesia diatur dengan bersandarkan pada asas-asas kewarganegaraan universal yaitu asas ius 
sanguinis (menentukan kewarganegaraan berdasarkan keturunan) dan asas ius soli (menentukan kerwarganegaraan berdasarkan tempat kelahiran). UU Kewarganegaraan telah jelas mengatur dan menetapkan siapa saja yang dapat tergolong warga negara terlepas dari unsur ras dan etnis, selama memenuhi syaratsyarat yang diatur oleh undang-undang. Negara memiliki kewajiban untuk menghormati, melindungi, menegakkan, dan memajukan upaya perlindungan dan penegakkan hak asasi warga negara atau masyarakat dengan melakukan upaya implementasi efektif dan konkrit atas instrumen-instrumen hukum yang berlaku di bidang hak asasi manusia dari segi hukum, politik, ekonomi, sosial, budaya, pertahanan dan keamanan. ${ }^{13}$

Penghormatan dan perlindungan terhadap HAM di negara Indonesia dapat dilihat pada konstitusi yang merupakan hukum dasar dan legitimasi akhir dari validitas suatu peraturan perundang-undangan nasional. Komitmen pemerintah dalam perlindungan dan penyelesaian segala bentuk diskriminasi ras dan etnis diwujudkan dalam Undang-Undang Nomor 40 Tahun 2008 tentang Penghapusan Diskriminasi Ras dan Etnis, yang berdasarkan prinsip persamaan kedudukan di dalam hukum bagi warga negara.

Pengertian diskriminasi dapat diketahui dalam ketentuan Pasal 1 angka 3 Undang-Undang Nomor 39 Tahun 1999 tentang Hak Asasi Manusia yang dimaksud dengan diskriminasi ialah :

"Setiap pembatasan, pelecehan, atau pengecualian yang langsung ataupun tak langsung didasarkan pada pembedaan manusia atas dasar agama, suku, ras, etnik, kelompok, golongan, status sosial, status ekonomi, jenis kelamin, bahasa, keyakinan politik, yang berakibat pengurangan, penyimpangan, atau penghapusan pengakuan, pelaksanaan atau penggunaan hak asasi dan kebebasan dasar dalam kehidupan baik individual maupun kolektif dala bidang politik, ekonomi, hukum, sosial, budaya, dan aspek kehidupan lainnya."

Sedangkan yang dimaksud diskriminasi ras dan etnis, menurut Pasal 1 ayat (1) Undnag-Undnag Nomor 40 Tahun 2008 tentang Penghapusan Diskriminasi Ras dan Etnis ialah "Segala bentuk pembedaan, pengecualian, pembatasan, atau pemilihan

${ }^{13}$ Frans Sayogi, Perlindungan Negara Terhadap Hak Kebebasan Beragama dalam Islam dan Hak Asasi Manusia Universal, Trans Pustaka, Tanggerang, 2003, hlm. 130 
berdasarkan pada ras dan etnis, yang mengakibatkan pencabutan atau pengurangan pengakuan, perolehan, atau pelaksanaan hak asasi manusia dan kebebasan dasar dalam suatu kesetaraan di bidang sipil, politik, ekonomi, sosial, dan budaya". Pada Pasal 4 huruf a dimuat mengenai penjelasan tindakan diskriminatif ras dan etnis berupa: "Memperlakukan pembedaan, pengecualian, pembatasan, atau pemilihan berdasarkan pada ras dan etnis, yang mengakibatkan pencabutan atau pengurangan pengakuan, perolehan, atau pelaksanaan hak asasi manusia dan kebebasan dasar dalam suatu kesetaraan di bidang sipil, politik, ekonomi, sosial, dan budaya.."

UU No. 40 Tahun 2008 ini menegaskan bahwa perlindungan dari diskriminasi ras dan etnis ditujukan kepada warga negara, dan pemerintah serta masyarakat sebagai pihak yang menyelenggarakan perlindungan dari segala bentuk tindakan diskriminasi ras dan etnis dengan melibatkan partisipasi seluruh warga negara yang dilaksanakan sesuai dengan ketentuan peraturan peundang-undangan. ${ }^{14}$ Berkaitan dengan hal tersebut pemberian perlindungan dan jaminan penghapusan diskriminasi ras dan etnis ditegaskan pada Pasal 5 dan Pasal 7, sebagai berikut :

Pasal 5:

"Penghapusan diskriminasi ras dan etnis wajib dilakukan dengan memberikan:

a. Perlindungan, kepastian, dan kesamaan kedudukan di dalam hukum kepada semua warga negara untuk hidup bebas dari diskriminasi ras dan etnis;

b. Jaminan tidak adanya hambatan bagi prakarsa perseorangan, kelompok orang, atau lembaga yang membutuhkan perlindungan dan jaminan kesamaan penggunaan hak sebagai warga negara; dan

c. Pemahaman kepada masyarakat mengenai pentingnya pluralisme dan penghargaan hak asasi manusia melalui penyelenggaraan pendidikan nasional."

Pasal 7

"Untuk penyelenggaraan perlindungan terhadap warga negara sebagaimana dimaksud dalam Pasal 6, pemerintah dan pemerintah daerah wajib:

a. memberikan perlindungan yang efektif kepada setiap warga negara yang mengalami tindakan diskriminasi ras dan etnis dan menjamin terlaksananya secara efektif upaya penegakan hukum terhadap setiap

\footnotetext{
${ }^{14}$ Hesti Armiwulan S., Diskriminasi Rasial Dalam Hukum HAM, Studi Tentang Diskriminasi Terhadap Etnis Tionghoa, Genta Publishing, Yogyakarta, 2013, hlm. 271
} 
tindakan diskriminasi yang terjadi, melalui proses peradilan yang dilakukan sesuai dengan ketentuan peraturan perundang-undangan;

b. menjamin setiap warga negara untuk memperoleh pertolongan, penyelesaian, dan penggantian yang adil atas segala kerugian dan penderitaan akibat diskriminasi ras dan etnis;

c. mendukung dan mendorong upaya penghapusan diskriminasi ras dan etnis, dan menjamin aparatur negara dan lembaga-lembaga pemerintahan bertindak sesuai dengan ketentuan peraturan perundangundangan; dan

d. melakukan tindakan yang efektif guna memperbarui, mengubah, mencabut, atau membatalkan peraturan perundang-undangan yang mengandung diskriminasi ras dan etnis."

Pasal 9

"Setiap warga negara berhak memperoleh perlakuan yang sama untuk mendapatkan hak-hak sipil, politik, ekonomi, sosial, dan budaya sesuai dengan ketentuan peraturan perundang-undangan, tanpa pembedaan ras dan etnis."

Upaya untuk memperkuat aturan tersebut maka dalam pelaksanaan penghapusan diskriminasi ras dan etnis dimuat aturan sanksi-sanksi baik pidana maupun perdata dalam Pasal 13 sampai dengan Pasal 21. Ketentuan mengenai sanksi ini menempatkan setiap orang yang merasa dirugikan dan menjadi korban dari adanya praktik diskriminasi ras dan etnis untuk mendapatkan atau memulihkan hak nya kembali.

Berdasarkan uraian di atas dapat diketahui bahwa instrumen hukum Indonesia tidak menghendaki terjadinya perbuatan diskriminasi ras dan etnis dalam bentuk dan ranah apapun. Penggolongan penduduk pada Pasal 111 ayat (1) angka 4 Perkaban No. 3 Tahun 1997 yang membagi warga negara menjadi tiga golongan tentu tidak sejalan dengan UU No. 40 Tahun 2008. Selain UU No. 40 Tahun 2008, Perkaban No. 3 Tahun 1997 sendiri juga bertentangan dengan Undang-Undang Dasar NRI Tahun 1945 Pasal 26 ayat (1), Pasal 27 ayat (1), 28B ayat (2), 28D ayat (1) dan (4), dan Pasal 28I ayat (2); Undang-Undang Nomor 39 Tahun 1999 tentang Hak Asasi Manusia, Pasal 1 angka 3 dan Undang-Undang Nomor 12 Tahun 2006 tentang Kewarganegaraan. Secara asas, maka penggolongan penduduk berdasarkan Pasal 111 Perkaban No. 3 Tahun 1997 tidak dapat diberlakukan berdasarkan asas lex superior derogate legi inferiori (peraturan 
perundang-undangan yang lebih tinggi mengesampingkan peraturan perundangundangan yang lebih rendah).

Peraturan mengenai penggolongan penduduk tersebut menyebabkan pembedaan, pengecualian, pembatasan, atau pemilihan berdasarkan pada ras dan etnis bagi warga negara Indonesia, yang mengakibatkan pengurangan pengakuan bagi warga negara keturunan Tionghoa dan Timur Asing, serta perolehan, atau pelaksanaan hak asasi manusia bagi hanya warga negara Indonesia asli yang diakui sebagai penduduk asli Indonesia, meskipun statusnya adalah Warga Negara Indonesia (WNI) dan diakui kewarganegaraannya secara hukum. Peraturan tersebut mengandung unsur diskriminatif yang dilaksanakan oleh Badan Pertanahan Nasional dalam pendaftaran tanah untuk proses peralihan hak karena pewarisan dalam melengkapi syarat administrasi pendaftaran hak tersebut sehingga dapat diproses oleh kantor pertanahan. Diskriminasi ras dan etnis dalam pembuatan surat keterangan waris, bertentangan dengan semangat pembangunan negara demokrasi (nation building), bahwa dengan adanya penggolongan penduduk khususnya dalam pembuatan surat keterangan waris, terjadi sebuah tindakan dan/atau kebijakan yang bertentangan dengan hukum yakni Undangundang Nomor 40 Tahun 2008 berupa tindakan pembedaan dan/atau pembatasan bagi golongan-golongan tertentu untuk memperoleh kebebasan dasar dan/atau pelaksanaan hak asasi manusia berupa kebutuhannya untuk memperoleh alat bukti yang menerangkan dirinya sebagai pihak yang berhak atas harta warisan yang ditinggalkan untuknya dan pula bertentangan dengan peraturan perundangundangan diatasnya.

Perkaban No. 3 Tahun 1997 tersebut di sisi lain juga mengakomodir mengenai peralihan hak atas tanah warga negara dalam hal pewarisan, sebab belum ada dasar hukumnya di Indonesia. Konsekuensi kemajemukan masyarakat Indonesia mengakibatkan adanya pluralitas praktik hukum perdata yang terdapat pada sistem hukum waris yang beragam. Diantaranya adanya hukum waris Islam yang berlaku untuk orang Islam yang diatur dalam Kompilasi Hukum Islam dan diperkuat dengan Instruksi Presiden Nomor 1 Tahun 1991 tentang Penyebarluasan Kompilasi Hukum Islam, hukum waris menurut KUH Perdata yang diatur pada 
Bab XII tentang Pewarisan Karena Kematian, serta hukum waris adat sesuai dengan masyarakat adat masing-masing. Dari ketiga sistem hukum waris tersebut, tidak ada satupun yang mengatur mengenai surat keterangan waris, sehingga ketentuan Pasal 111 ayat (1) angka 4 Perkaban No. 3 Tahun 1997 tersebut menjadi jalan keluar bagi warga negara untuk mendapat kepastian hukum sebagai konsekuensi adanya pluralitas sistem hukum waris dimana warga negara mempunyai pilihan hukum untuk menundukkan diri. Unsur diskriminasi yang terkandung dalam Pasal 111 ayat (1) angka 4 tersebut masih digunakan disebabkan karena hingga saat ini belum terdapat unifikasi hukum waris di Indonesia.

Pembedaan Pihak yang Berwenang Membuat Surat Tanda Bukti Sebagai Ahli Waris pada Pasal 111 ayat (1) huruf c angka 4 PMNA/Kepala BPN Nasional No. 3 Tahun 1997 tentang Pelaksanaan PP No. 24 Tahun 1997 tentang Pendaftaran Tanah dalam Menjamin Kepastian Hukum Bagi Ahli Waris

Penerbitan surat tanda bukti sebagai ahli waris menurut Pasal 111 Perkaban No. 3 Tahun 1997 dibagi ke tiga institusi. Pembagian tersebut didasarkan pada penggolongan penduduk dalam Pasal 111 Perkaban tersebut. Bagi WNI penduduk asli maka surat keterangan ahli waris dikuatkan oleh Kepala Desa/Lurah dan camat, bagi WNI keturunan Tionghoa menggunakan akta keterangan hak mewaris dari notaris serta WNI keturunan Timur Asing lainnya menggunakan surat keterangan waris dari Balai Harta Peninggalan.

\section{a. Ahli Waris yang Dikuatkan oleh Kepala Desa/Lurah dan Camat}

Surat keterangan ahli waris bagi warga negara Indonesia Asli atau Pribumi dibuat oleh para ahli waris dengan disaksikan oleh 2 (dua) orang saksi dan kemudian dikuatkan oleh Kepala Desa/Lurah dan Camat tempat pewaris meninggal dunia. Merujuk pada ketentuan Pasal 111 ayat (1) huruf c angka 4 Perkaban No. 3 Tahun 1997, Kepala Desa/Lurah dan Camat diberi kewenangan untuk menguatkan surat keterangan ahli waris yang dibuat sendiri oleh ahli waris. Jika ditinjau dari tugas dan kewenangannya Kepala Desa diatur pada Undang-Undang Nomor 6 Tahun 2014 tentang Desa pada Pasal 26 ayat (1) dan ayat (2), dan tugas serta wewenang Lurah Pasal 229 ayat (4) dan Camat diatur pada Pasal 225 ayat (1) Undang-Undang Nomor 23 Tahun 2014 tentang Pemerintahan Daerah. Pada ketentuan-ketentuan tersebut, tidak terdapat 
atuaran yang mengatur mengenai kewenangan Kepala Desa/Lurah dan Camat dalam hal menguatkan surat keterangan ahli waris warga Indonesia asli atau pribumi sebagaimana dimaksud Pasal 111 ayat (1) huruf c angka 4 Perkaban No. 3 Tahun 1997. Kewenangan lurah dan camat dalam menguatkan surat keterangan waris dikaitkan dalam kewenangannya sebagai bagian dari pelaksana urusan pemerintah di daerah yang dalam hal ini merupakan tindakan keperdataan, oleh sebab itu tidak memenuhi unsur sebagai suatu keputusan tata usaha negara. Lurah dan camat di sini diartikan bertindak dalam lapangan hukum keperdataan dan tunduk pada hukum perdata, yang dalam hukum administrasi negara dikenal dengan Privaatrechtelijke rechtshandelingen ${ }^{15}$ (tindakan-tindakan keperdataan). Apabila terjadi permasalahan di kemudian hari, maka dapat mengajukan gugatan ke lingkungan peradilan umum sebab keterangan waris merupakan alat bukti di ranah hukum perdata.

Kepastian hukum Surat Keterangan Ahli Waris tersebut ialah merupakan surat di bawah tangan dan berisi pernyataan bahwa ahli waris yang membuat pernyataan tersebut merupakan ahli waris yang sah dari pewaris. Sedangkan kedudukan Kepala Desa/Lurah dan Camat sebatas mengesahan kependudukan warganya dan mencocokkan surat keterangan waris dengan dokumen yang dilampirkan. Terdapat dua bentuk surat keterangan waris yang dibuat dalam bentuk akta di bawah tangan, yaitu: ${ }^{16}$

1) keterangan waris yang diterbitkan dan ditandatangani langsung oleh Camat setempat atas dasar pernyataan ahli waris yang bersangkutan, lengkap dengan memakai kepala dan nomor surat dinas kantor Camat;

2) keterangan waris yang dibuat dan ditandatangani bersama oleh para ahli waris yang kemudian dikuatkan oleh lurah setempat dan diketahui oleh Camat.

Akta di bawah tangan memiliki kekuatan pembuktian sepanjang para pihak mengakuinya atau tidak ada penyangkalan dari salah satu pihak terkait akta

\footnotetext{
$122-123$

15 Ridwan HR, Hukum Admiinistrasi Negara, Edisi Revisi, Cetakan 8, Rajawali Press, Jakarta, 2013, hlm.

${ }^{16}$ Gusti Riyan Sezar, "Pembuatan Alat Bukti Sebagai Abli Waris Oleh Notaris Ditinjau Dari Undang-Undang Nomor 40 Tahun 2008 Tentang Penghapusan Diskriminasi Ras Dan Etnis, Tesis Program Studi Magister Kenotariatan Fakultas Hukum UGM, Yogyakarta, 2014, hlm. 60
} 
tersebut. Apabila salah satu pihak tidak mengakuinya, beban pembuktian diserahkan kepada pihak yang menyangkal akta tersebut, serta penilaian terhadap penyangkalan atas bukti tersebut diserahkan sepenuhnya kepada Hakim. ${ }^{17}$ Berbeda dengan kekuatan pembuktian akta autentik yang terkuat dan terpenuh dalam artian dianggap sah dan benar tanpa perlu pembuktian seperti pada akta dibawah tangan yang tergantung pada para pihak yang mengakuinya.

\section{b. Notaris}

Notaris adalah salah satu pihak yang memiliki wewenang untuk membuat keterangan waris berdasarkan Pasal 42 ayat (1) Peraturan Pemerintah No. 24 Tahun 1997 tentang Pendaftaran Tanah jo Pasal 111 ayat (1) huruf c angka 4 Perkaban No. 3 Tahun 1997, diantaranya:

1. Pada Pasal 42 ayat (1) Peraturan Pemerintah No. 24 Tahun 1997 tentang Pendaftaran Tanah mengatur mengenai pendaftaran peralihan hak karena pewarisan, menerangkan mengenai kebutuhan persyaratan berupa dokumen-dokumen yang salah satunya ialah surat tanda bukti sebagai ahli waris, dan;

2. dalam Pasal 111 ayat (1) huruf c angka 4 Peraturan Menteri Negara Agraria/Kepala BPN No. 3 Tahun 1997 yang menyebutkan wewenang notaris membuat keterangan waris bagi warga negara Indonesia Keturunan Tionghoa dengan akta keterangan hak mewaris dari Notaris.

Notaris dalam pengertian lebih luas yang dijelaskan lebih lanjut dalam peraturan perundang-undangan adalah pejabat umum yang berwenang membuat akta autentik dan memiliki kewenangan lain sebagaimana dimaksud dalam Undang-Undang Jabatan Notaris. ${ }^{18}$ Akta autentik yang dibuat notaris merupakan alat pembuktian tertulis yang terkuat dan terpenuh. Sebagaimana dimaksud mengenai kewenangan Notaris dalam bunyi Pasal 15 UndangUndang Nomor 2 Tahun 2014 tentang Perubahan Undang-Undang Nomor 30 Tahun 2004 tentang Jabatan Notaris ;

(1)Notaris berwenang membuat Akta autentik mengenai semua perbuatan, perjanjian, dan penetapan yang diharuskan oleh peraturan perundangundangan dan/atau yang dikehendaki oleh yang berkepentingan untuk

\footnotetext{
${ }^{17}$ Habib Adji, Sekilas Dunia Notaris dan PPAT di Indonesia, Mandar Maju, Bandung, 2009., hlm. 33-34

${ }^{18}$ Lihat Pasal 1 ayat (1) Undang-Undang Nomor 2 Tahun 2014 Tentang Perubahan Undang-Undang Nomor 30 Tahun 2004 Tentang Jabatan Notaris
} 
dinyatakan dalam Akta autentik, menjamin kepastian tanggal pembuatan Akta, menyimpan Akta, memberikan grosse, salinan dan kutipan Akta, semuanya itu sepanjang pembuatan Akta itu tidak juga ditugaskan atau dikecualikan kepada pejabat lain atau orang lain yang ditetapkan oleh undang-undang.

(2)Selain kewenangan sebagaimana dimaksud pada ayat (1), Notaris berwenang:

a. mengesahkan tanda tangan dan menetapkan kepastian tanggal surat di bawah tangan dengan mendaftar dalam buku khusus;

b. membukukan surat di bawah tangan dengan mendaftar dalam buku khusus;

c. membuat kopi dari asli surat di bawah tangan berupa salinan yang memuat uraian sebagaimana ditulis dan digambarkan dalam surat yang bersangkutan;

d. melakukan pengesahan kecocokan fotokopi dengan surat aslinya;

e. memberikan penyuluhan hukum sehubungan dengan pembuatan Akta;

f. membuat Akta yang berkaitan dengan pertanahan; atau

g. membuat Akta risalah lelang.

(3)Selain kewenangan sebagaimana dimaksud pada ayat (1) dan ayat (2), Notaris mempunyai kewenangan lain yang diatur dalam peraturan perundangundangan.

Ada dua macam akta yang dapat dibuat oleh Notaris, yakni akta yang dibuat oleh Notaris dan Akta yang dibuat di hadapan Notaris. Akta yang dibuat oleh Notaris dalam praktik Notaris disebut Akta Relaas atau Akta Berita Acara berisi uraian Notaris mengenai apa yang dilihat dan apa yang disaksikan oleh Notaris sendiri atas permintaan para pihak, agar tindakan atau perbuatan para pihak yang dilakukan tersebut kemudian dituangkan kedalam akta Notaris. Sedangkan akta yang dibuat di hadapan Notaris disebut Akta Pihak yang berisi uraian atau keterangan, pernyataan para pihak yang diberikan atau diceritakan dihadapan Notaris. ${ }^{19}$ Akta Notaris merupakan akta autentik sebab bentuk dan tata cara pembuatan akta ditetapkan melalui Undang-Undang. ${ }^{20}$ Pasal 1868 KUHPerdata mengatur bahwa suatu akta autentik merupakan "akta yang dibuat dalam bentuk yang ditentukan undang-undang oleh atau di hadapan pejabat umum yang berwenang untuk itu dan di tempat akta itu dibuat."

${ }^{19}$ Habib Adjie, Kebatalan dan Pembatalan Akta Notaris, PT Refika Aditama, Bandung, 2013, hlm. 10

20 Pasal 1 angka 7, Pasal 15 mengatur mengenai kewenangan Notaris, Pasal 38 mengenai bentuk akta Notaris, Undang-Undang Nomor 30 Tahun 2004 perubahan Undang-Undang Nomor 2 Tahun 2014 tentang Jabatan Notaris 
Akta autentik yang dibuat notaris merupakan alat pembuktian tertulis yang terkuat dan terpenuh, untuk itulah peran notaris berhubungan dengan pembuktian di ranah hukum perdata khususnya dalam hal alas hak dalam peralihan hak karena pewarisan menjadi penting tanpa harus membedakan dari mana golongan pihak yang menghadap kepadanya. Kekuatan pembuktian akta autentik:21

1. Lahiriah (uitwendige bewijskracht); Jika dilihat dari luar (lahirnya) sebagai akta autentik sebab sesuai dengan aturan hukum yang sudah ditentukan mengenai syarat akta autentik, maka akta tersebut berlaku sebagai akta autentik sampai terbukti sebaliknya. Artinya untuk meyangkal kedudukan akta sebagai akta autentik, harus dibuktikan terlebih dahulu bahwa secara lahiriah akta tersebut bukan akta autentik.

2. Formal (Formale bewijskracht); secara formal menjamin kebenaran dan kepastian tanggal, hari, bulan, pukul, para pihak serta tanda tangan atas perbuatan hukum dalam akta.

3. Materil (Materiele bewijskracht); kepastian materi suatu akta, apa yang dimuat/dituangkan ke dalam akta berlau sebagai benar dan pembuaktian yang sah sampai dibuktikan sebalikya.

Praktik selama ini mengenai surat keterangan waris menurut Tan Thong Kie dalam Habib Adjie, ${ }^{22}$ pembuatan surat keterangan waris oleh notaris tidak ada dasar peraturan perundang-undangan yang mendasarinya. Surat keterangan waris hanya merupakan surat di bawah tangan yang dibuat oleh notaris, yang nilai pembuktiannya tidak sempurna dan sama nilanya dengan surat-surat lainnya yang biasa dikeluarkan notaris misalnya surat keterangan magang, dan covernote.

Keterangan waris dapat saja dibuat dengan bersandar pada ketetentuan Pasal 15 ayat (1) dan ayat (3) UU Jabatan Notaris, namun hal itu masih menjadi multitafsir terhadap pembuatan bentuk keterangan waris oleh Notaris. Artinya keterangan waris dimungkinkan dalam beberapa bentuk yang dapat dijadikan pilihan oleh Notaris dalam pembuatan keterangan waris.

\section{c. Balai Harta Peninggalan}

Balai Harta Peninggalan merupakan unit pelaksana teknis yang berasa di lingkungan Kantor Wilayah Kementerian Hukum dan Hak Asasi Manusia di

${ }^{21}$ Op. cit., Habib Adjie, Kebatalan ...., hlm. 18-20

22 Op., cit., Habib Adjie. Pembuktian Sebagai Ahli Waris Dengan Akta Notaris..., hlm. 39 
bawah divisi pelayanan hukum dan HAM. Namun secara teknis, berdasarkan Peraturan Menteri Hukum dan Hak Asasi Manusia RI Tanggal 1 Maret 2005 Nomor M-01.PR.07.10 Tahun 2005 tentang Organisasi dan Tata Kerja Kantor Wilayah Departemen Hukum dan Hak Asasi Manusia Republik Indonesia, bertanggung jawab langsung pada Direktorat Jendral Administrasi Hukum Umum melalui Direktorat Perdata. ${ }^{23}$ Secara kedudukan, berdasarkan ketentuan Pasal 14 ayat 1 dari Instruksi Voor de Gouvernements Landmeters dalam Stbl. 1916 No. 517, jo Surat Menteri Dalam Negeri c.q. Kepala Direktorat Pendaftaran Tanah Direktorat Jenderal Agraria Departemen Dalam Negeri tanggal 20 Desember 1969 Nomor: DPT/12/63/12/69 jo. Perkaban No. 3 Tahun 1997 merupakan instansi yang berwenang menerbitkan Surat Keterangan Hak Mewaris Untuk Golongan Timur Asing.

Perlaksanaan tugas pokok dan fungsi Balai Harta Peninggalan berpedoman pada Pasal 2 dan Pasal 3 Surat Keputusan Menteri Kehakiman Republik Indonesia tanggal 19 Juni 1980 Nomor M.01.PR.07.01-80 Tahun 1980 Tentang Organisasi dan Tata Kerja Balai Harta Peninggalan. ${ }^{24}$ Dalam Pasal 2 dan 3 Surat Keputusan Menteri Kehakiman tersebut memuat Tugas Pokok dan Fungsi Balai Harta Peninggalan sebagai berikut :

Pasal 2

"Tugas Balai Harta Peninggalan ialah mewakili dan mengurus kepentingan orang- orang yang karena hukum atau keputusan Hakim tidak dapat menjalankan sendiri kepentingannya berdasarkan peraturan perundang- undangan yang berlaku."

Pasal 3

“Untuk menyelenggarakan tugas tersebut pada pasal 2, Balai Harta Peninggalan mempunyai fungsi : (1) Melaksanakan penyelesaian masalah Perwalian, Pengampunan, Ketidak Hadiran dan Harta Peninggalan yang tidak ada kuasanya dan lain- lain masalah yang diatur dalam Peraturan Perundang- undangan. (2) Melaksanakan Pembukuan dan Pendaftaran surat Wasiat sesuai dengan Peraturan Perundangundangan. (3) Melaksanakan penyelesaian masalah Kepailitan sesuai dengan Peraturan Perundang-undangan."

${ }^{23}$ Balai Harta Peninggalan Jakarta, http:/ /www.bhpjakarta.info.go.id diakses pada 28 November 2018

${ }^{24}$ Ibid 
Kewenangan Balai Harta Peninggalan yang diatur pada Pasal 111 ayat (1) huruf c angka 4 Perkaban No. 3 Tahun 1997 merupakan bagian dari pelaksana urusan pemerintah yang diartikan sebagai tindakan pemerintah di lapangan keperdataan. Keterangan waris yang dikeluarkan oleh Balai Harta Peninggalan hanya merupakan surat di bawah tangan yang nilai pembuktiannya tidak sempurna dan sama nilanya dengan surat-surat lainnya yang diterbitkan oleh istansi pemerintah (dalam urusan adminstratif). Sama seperti halnya Kepala Desa/Lurah dan Camat, apabila terjadi permasalahan di kemudian hari, maka dapat mengajukan gugatan, ke lingkungan peradilan umum karena surat keterangan waris merupakan alat bukti di ranah hukum perdata.

Pembedaan pihak yang berwenang untuk membuat surat keterangan waris tersebut sejatinya tidak efisien diterapkan. Selain itu, pembedaan yang disebabkan penggolongan penduduk berdasarkan Perkaban No. 3 Tahun 1997 juga menimbulkan diskriminasi dan birokrasi yang tidak panjang (tidak terpadu). Sehingga, ke depan, perlu penyempurnaan sesuai dengan dinamika perkembangan hukum dan konteks masyarakat terkait dengan waris.

\section{Penutup}

Berdasarkan hasil analisis yang telah diuraikan dalam bab sebelumnya, maka dapat ditarik kesimpulan sebagai berikut: pertama, penggolongan penduduk pribumi non pribumi pada Pasal 111 ayat (1) huruf c angka 4 Perkaban No. 3 Tahun 1997 jika ditinjau dari Undang-Undang Nomor 40 Tahun 2008 tentang Diskriminasi Ras dan Etnis memenuhi unsur tindakan diskriminasi ras dan etnis. Selain itu, Perkaban No. 3 Tahun 1997 juga bertentangan dengan UUD NRI 1945 dan UU Kewarganegaraan. Apabila menggunakan asas lex superior derogate legi inferiori, maka peraturan penggolongan penduduk dalam Perkaban tersebut tidak mempunyai kekuatan hukum yang mengikat.

Kedua, pembedaan pihak yang berwenang dalam pembuatan keterangan waris dapat memberikan kepastian hukum sebab hanya Pasal 111 ayat (1) huruf c angka 4 Perkaban No. 3 Tahun 1997-lah yang mengatur secara lebih khusus mengenai pembuatan keterangan waris, namun perlu penyempurnaan yang 
selaras dengan perkembangan hukum dan tujuan negara yang terdapat dalam kosntitusi.

Berdasarkan simpulan tersebut, maka peneliti mengajukan rekomendasi, pertama kepada pemangku kewajiban, negara wajib melindungi dan menegakkan hak asasi warga negara atau masyarakat. Bagi pemerintah harus ada tindakan tegas dalam penyusunan hukum waris di Indonesia dengan tetap memperhatikan keragaman nilai-nilai agama, sosial, dan budaya dengan unifikasi hukum waris. Unifikasi hukum waris dalam pandangan penulis tidak berarti menjadikan hanya satu hukum waris saja yang diterapkan bagi warga negara, melainkan unifikasi hukum waris sebagai wadah bagi regulasi pewarisan di Indonesia yang di dalamnya memuat pilihan hukum sesuai sistem hukum waris yang masih berlaku di masyarakat. Diantaranya sistem hukum waris adat, hukum waris KUH Perdata dan hukum Islam yang berlaku bagi warga negara yang menundukkan diri pada salah satu sistem hukum tersebut. Dan ketentuan Pasal 111 ayat (1) huruf c angka 4 Peraturan Menteri Negara Agraria/Kepala BPN No. 3 Tahun 1997 tentang Ketentuan Pelaksanaan Peraturan Pemerintah No. 24 Tahun 1997 tentang Pendaftaran Tanah tersebut dapat dicabut. Dan tidak terdapat regulasi yang mengandung unsur diskriminatif dalam sistem hukum di Indonesia.

Kedua, bagi pihak yang berwenang dalam pembuatan keterangan waris hendaknya dilakukan oleh satu pejabat saja, agar warga negara diperlakukan adil dan sama di hadapan hukum. Mengacu pada hal tersebut maka Notaris ialah pejabat yang dapat ditunjuk kemudian oleh peraturan perundang-undangan untuk menjadi satu-satunya pihak berwenang membuat keterangan waris. Keterangan waris merupakan instrumen alat bukti yang dipergunakan ahli waris untk membuktikan bahwa ahli waris adalah yang sebenarnya. Berkaitan dengan pembuktian tersebut, Notaris memiliki kewenangan membuat akta autentik berdasarkan Undang-Undang dan akta notaris memiliki kekuatan pembuktiannya terkuat dan terpenuh. Notaris juga merupakan pejabat yang berada pada lingkup hukum perdata yang sesuai dengan keterangan waris yang berada dalam ranah perdata pula. 


\section{Daftar Pustaka}

\section{Buku}

Adji, Habib, Sekilas Dunia Notaris dan PPAT di Indonesia, Mandar Maju, Bandung, 2009. , Kebatalan dan Pembatalan Akta Notaris, PT Refika Aditama, Bandung, 2013. , Pembuktian Sebagai Ahli Waris Dengan Akta Notaris, Mandar Maju, Bandung, 2008.

Budiono, Herlin, Kumpulan Tulisan Hukum Perdata di Bidang Kenotariatan, Citra Aditya Bakti, Bandung, 2013.

HR, Ridwan, Hukum Administrasi Negara, Edisi Revisi, Cetakan 8, Rajawali Press, Jakarta, 2013.

Qamar, Nurul, Hak Asasi Manusia Dalam Negara Hukum Demokrasi (Human Rights In Democratiche Rechtsstaat), Sinar Grafika, Jakarta Timur, 2013.

S., Hesti Armiwulan, Diskriminasi Rasial Dalam Hukum HAM, Studi Tentang Diskriminasi Terhadap Etnis Tionghoa, Genta Publishing, Yogyakarta, 2013.

Sayogi, Frans, Perlindungan Negara Terhadap Hak Kebebasan Beragama dalam Islam dan Hak Asasi Manusia Universal, Trans Pustaka, Tanggerang, 2003.

Suhardana, F.X., Hukum Perdata, Buku Panduan Mahasiswa, PT. Prenhallindo, Jakarta, 2001.

Tobing, GHS. Lumban, Peraturan Jabatan Notaris, Erlangga, Jakarta, 1999.

\section{Jurnal}

Pramana, RM. Henky Wibawa Bambang, Suhariningsih, dan Abdul Rachmad Boediono, "Analisis Yuridis Surat Keterangan Ahli Waris Sebagai Alat Bukti", Jurnal Hukum, Magister Ilmu Hukum dan Kenotariatan 2014, Universitas Brawijaya.

Yoga, I Gusti Kade Prabawa Maha, Afifah Kusumadara dan Endang Sri Kawuryan, "Kewenangan Notaris dalam Pembuatan Surat Keterangan Waris untuk Warga Negara Indonesia," Jurnal Ilmiah Pendidikan Pancasila dan Kewarganegaraan, Vol. 3 Nomor 2 Desember 2018.

\section{Tesis}

Sezar, Gusti Riyan, "Pembuatan Alat Bukti Sebagai Ahli Waris Oleh Notaris Ditinjau Dari Undang-Undang Nomor 40 Tahun 2008 Tentang Penghapusan Diskriminasi Ras Dan Etnis," Tesis, Program Studi Magister Kenotariatan Fakultas Hukum UGM, Yogyakarta, 2014.

\section{Peraturan Perundang-Undangan}

Undang-Undang Dasar Negara Republik Indonesia Tahun 1945.

Kitab Undang-Undang Hukum Perdata (KUH Pedata).

Kompilasi Hukum Islam (KHI). 
Undang-Undang Nomor 5 Tahun 1960 Tentang Peraturan Dasar Pokok-Pokok Agraria; Tambahan Lembaran Negara Nomor 2043.

Undang-Undang Nomor 30 Tahun 2004 tentang Jabatan Notaris; Tambahan Lembaran Negara Republik Indonesia Nomor 4432

Undang-Undang Nomor 12 Tahun 2006 tentang Kewarganegaraan Republik Indonesia; Lembaran Negara Republik Indonesia Tahun 2006 Nomor 63

Undang-Undang Nomor 40 Tahun 2008 tentang Penghapusan Diskriminasi Ras dan Etnis; Tambahan Lembaran Negara Republik Indonesia Nomor 4919

Undang-Undang Nomor 2 Tahun 2014 tentang Perubahan atas Undang-Undang Nomor 30 Tahun 2004 tentang Jabatan Notaris; Tambahan Lembaran Negara Republik Indonesia Nomor 5491

Peraturan Menteri Negara Agraria/Kepala BPN No. 3 Tahun 1997 tentang Ketentuan Pelaksanaan Peraturan Pemerintah No. 24 Tahun 1997 tentang Pendaftaran Tanah.

\section{Internet}

Balai Harta Peninggalan Jakarta, http:/ / www.bhpjakarta.info.go.id diakses pada 28 November 2018. 